\title{
Doğal Zeolitlerin Okratoksin A Adsorbsiyon Kapasitelerinin Geliştirilmesi ve Üzüm Suyundan Okratoksin A Uzaklaştırma İşleminde Kullanılması
}

\author{
Levent ŞEN $1^{*}$
}

\begin{abstract}
Öz
Okratoksin A (OTA), üzüm ve üzüm ürünlerinde en sık rastlanan mikotoksindir. Zeolitlerin gıda ve yemlerde bulunan mikotoksinlerin detoksifikasyonlarında kullanımı son yıllarda önemli bir araştırma konusu haline gelmiştir. Çalışmada, iki farklı boyutta (100 $\mu \mathrm{m}$ ve $1-3 \mathrm{~mm})$ doğal zeolit (DZ), OTA adsorbsiyon kapasitesinin artırılması amaciyla Oktadesil trimetil amonyum bromid (ODTMA) ile muamele edilerek modifiye organo-zeolit (MZ) sentezi gerçekleştirilmiş̧ir. Sentezlenen MZ'lerin OTA adsorbsiyon kapasiteleri DZ'ler ile birlikte değerlendirilmiştir. Bu amaçla pH'ı 3'e ayarlanmış OTA içeren tampon çözeltilere ilave edilen DZ ve MZ'lerin maksimum adsorbsiyon gerçekleştirdiği miktar, süre ve sıcaklıklar belirlenerek, üzüm suyundan OTA adsorbsiyonu için optimum koşullar belirlenmiştir. Gerek tampon gerekse de üzüm suyu denemelerinde MZ’ler DZ’lere göre daha iyi adsorbsiyon sonuçları vermişlerdir. $10 \mathrm{ng} . \mathrm{mL}^{-1} \mathrm{OTA}$ içeren üzüm suyu, $5 \%$ oranında ilave edilen $\mathrm{DZ}$ ve MZ'ler eşliğinde $45^{\circ} \mathrm{C}$ sıcaklıkta 120 dakika karıştırma süresine tabi tutulduğunda en yüksek adsorbsiyon oranı $89.68 \% \pm 1.48$ ile MT örneğinde gerçekleşmiştir. 1-3 mm boyutundaki zeolit tipleri tüm denemelerde toz formunda olanlara göre daha düşük adsorbsiyon yeteneği göstermiştir. DZ’lerin yüzey yapısının modifiye edilerek OTA adsorbsiyon kapasitesinin artırılması ileüzüm suyundan OTA uzaklaştırılmasında aktif karbonlara alternatif olarak kullanılabileceği düşünülmektedir.
\end{abstract}

Anahtar Kelimeler: Okratoksin A, Zeolit, Adsorbsiyon, Organo-zeolit.

\section{Improvement of Ochratoxin A Adsorption Capacity of Natural Zeolites and Its Use in the Removal of Ochratoxin A from Grape Juice}

\begin{abstract}
Octratoxin A (OTA) is the most common mycotoxin in grape and grape products. The use of zeolites in detoxification of mycotoxins in food and feed has become an important research topic in recent years. In this study, Modified organozeolite (MZ) synthesis was carried out by treating natural zeolite (DZ) in two different sizes (100 $\mu \mathrm{m}$ and 1-3 mm) with octadecyl trimethyl ammonium bromide (ODTMA) in order to raise the OTA adsorption capacity. OTA adsorption capacities of synthesized MZs were evaluated together with DZ. For this purpose, optimum conditions for OTA adsorption from grape juice were determined by determining the amount, time and temperature at which DZ and MZ added to buffer solutions containing OTA adjusted to $\mathrm{pH} 3$ were subjected to maximum adsorption. In both buffer and grape juice trials, MZs gave better adsorption results than DZs. Grape juice containing $10 \mathrm{ng}$. $\mathrm{mL}^{-1} \mathrm{OTA}$ was subjected to stirring for $120 \mathrm{~min}$ at $45^{\circ} \mathrm{C}$ in the presence of $\mathrm{DZ}$ and $\mathrm{MZ}$ added at 5\%, resulting in the highest adsorption rate of $89.68 \% \pm 1.48$ for MT added samples. Zeolite types $1-3 \mathrm{~mm}$ in size showed lower adsorption ability than those in powder form in all experiments. It is thought that the surface structure of DZs can be modified to increase the OTA adsorption capacity and be used as an alternative to activated carbons in the removal of OTA from grape juice.
\end{abstract}

Keywords: Octratoxin A, Zeolite, Adsorbtion, Organozeolite.

${ }^{1}$ Giresun Üniversitesi, Mühendislik Fakültesi, Gıda Mühendisliği Bölümü, Giresun, Türkiye, levent.sen@giresun.edu.tr

${ }^{1}$ https://orcid.org/0000-0002-4979-7466 


\section{Giriş}

Dünyada kültürü yapılan en eski meyve türlerinden birisi olan üzüm (Vitis vinifera L.), iklim ve toprak istekleri yönünden çok seçici olmaması, çoğalma yöntemlerinin kolaylığ 1 ve çok çeşitli şekillerde tüketilebilme olanağı nedeniyle dünyadaki en yaygın kültür bitkilerinden birisidir olup tarihçesi M.Ö 5000-6000 yıllarına kadar dayanmaktadır (Akova, 2009). Üzümün yüksek şeker içeriğinin yanında mineral maddelerden kalsiyum, potasyum, sodyum ve demir içeriği yüksek, A, B1, B2, Niasin ve C vitaminleri yönünden de önemli bir kaynak olduğu kabul edilmektedir (Cabaroğlu ve Y1lmaztekin, 2006).

Mikotoksinler funguslar tarafından üretilen ve çeşitli tarımsal ürünlere hasat öncesinde ya da hasattan sonraki herhangi bir aşamada bulaşabilen toksik metabolitlerdir (Sherif ve ark., 2009). Olumsuz şartlara maruz kalmış ve toksijenik küf gelişimi sonucu mikotoksin oluşumu gerçekleşmiş tarımsal ürünler tüketildiğinde insan ve hayvanlarda toksik etkiler oluşturmaktadır. "Mikotoksikozis" ise mikotoksin oluşmuş gıda ve yemlerin tüketilmesiyle ortaya çıkan hastalıklardır (Seo ve Yu, 2005). Gıda ve yem maddelerindeki mikotoksin oluşumu hem hayvan hem de insan sağlığını tehdit etmektedir (Narayanasamy, 2006). Birleşmiş Milletler Gıda ve Ziraat Örgütü (FAO) dünya gıda ürünlerinin her y1l en az \%25'inin mikotoksinler tarafından etkilendiğini rapor etmiştir (Breyden, 2007).

Okratoxin A (OTA), 1965 yılında Güney Afrika'da Aspergillus ochraceus ile aşılanmış mısır unundan izole edilerek bu mikrofungusun toksik metaboliti olarak keşfedilmiş, 1967 yılında ise kimyasal yapısı tam olarak karakterize edilmiş ve ilk defa Aspergillus ochraceus’tan izole edildiği için “okratoksin” adı verilmiştir (Malir ve ark., 2016). Daha sonraki yıllarda yapılan çalışmalar, OTA'nın birçok Aspergillus ve Penicillium cinsi küfler tarafından üretilen karsinojenik, genotoksik, teratojenik, immunotoksik ve nefrotoksik etkileri olan bir mikotoksin olduğunu ortaya koymuştur (Jackson ve Al-Tahaer, 2008). Ayrıca bileşiğin Balkan yarımadasının merkezindeki kırsal bölgelerde rastlanan, öldürücü bir böbrek hastalığı olan "Balkan Endemik Nefropati” sinden (Jackson and AlTaher, 2008) ve üriner bölge tümörlerinden sorumlu olduğu ifade edilmektedir (Battilani et al., 2003). Bu bilgiler 1şığında, OTA, 1993 yılında Dünya Sağlık Örgütü Uluslararası Kanser Araştırma Enstitüsü (IARC) tarafından olası insan karsinojeni (2B) sınıfına dahil edilmiştir (Malir ve ark., 2016).

OTA içeren gıdaların tüketilmesinin muhtemel sağlık problemlerine neden olacağının düşünülmesi üzerine Avrupa Birliği ülkeleri, kavrulmuş kahve $\left(5 \mu \mathrm{g} / \mathrm{kg}^{-1}\right)$, instant kahve (10 $\mu \mathrm{g}$ / $\left.\mathrm{kg}^{-1}\right)$, üzümden yapılan şaraplar $\left(2 \mu \mathrm{g} / \mathrm{kg}^{-1}\right)$, üzüm suları $\left(2 \mu \mathrm{g} / \mathrm{kg}^{-1}\right)$ ve kurutulmuş üzümler $(10 \mu \mathrm{g}$ / kg-1) gibi birçok üründe maksimum tespit miktarları belirlemiştir (European Commission, 2006). 
1996’ya kadar A. niger var. niger'in OTA üretebildiği rapor edilmesine rağmen, üzümlerde yalnızca A. ochraceus'un OTA ürettiği düşünülüyordu. Zimmer ve Dick (1996) tarafindan üzüm suyu ve şarapta önemli miktarlarda belirlenen OTA kaynağının siyah sporlu iki Aspergillus türü olan A. carbonarius ve A. niger olduğu belirtilmişstir. A. niger’in nigri (siyah aspergilli) ve Circumdanti alt şubesi üyelerinin, özellikle de A. carbonarius’un üzümlerde kolonileşmeden ve OTA üretiminden sorumlu olan türler olduğu belirtilmektedir. Bunlar genellikle sporlarını hava ile nakleden toprak kökenli türler olup Akdeniz, tropik ve subtropik iklimlerde olgunlaşan ürünlere kontamine olabilmektedirler (Jackson ve Al-Tahaer, 2008).

Avrupa'da yapılan geniş çaplı araştırmaların sonucunda $A$. carbonarius'un büyük ölçüde üzüm, şarap ve şarap meyvelerinde OTA kontaminasyonundan sorumlu olduğu belirlenmiştir. OTA sadece şarapta değil, aynı zamanda diğer üzüm ürünlerine de kontamine olmaktadır. İngiltere Tarım, Balık ve Gıda Bakanlığı'nın 1999 yılında yaptığı bir çalışmada 20 üzüm suyu örneği analiz edilmiş, biri dışında örneklerin tamamının 20 ila 2050 ng. $L^{-1}$ seviyelerinde OTA içerdiği tespit edilmiştir. Almanya'da 1995 ile 1998 yılları arasında beyaz üzüm suyu örnekleri incelenmiş (n=38), örneklerin 7’sinin 10 ng. $\mathrm{L}^{-1}$, den az, geriye kalanların ise 10 ila 1300 ng. $\mathrm{L}^{-1}$ düzeylerinde OTA içerdiği saptanmıştır (Battilani, 2006).

Mikotoksinler ile kontamine olmuş gıda ve yem maddelerinden mikotoksinlerin uzaklaştırılması amacıyla geliştirilmiş yöntemler fiziksel (1S1 uygulaması, 1şınlama, ultrasonik uygulamalar), fizikokimyasal (zeolit, aktif karbon, bentonit uygulmaları), kimyasal (hidrojen peroksit, amonyum hidroksit, bisülfit uygulamaları) ve biyolojik (laktik asit bakterileri, rumen mikroorganizmaları v.b) yöntemler olarak sınıflandırılmaktadır (Kabak ve Var, 2005; Varga ve ark., 2014). Mikotoksinlerin detoksifikasyonu ile ilgili bahsi geçen bu yöntemler gıda ve yemlerin fiziksel ve kimyasal özelliklerine göre sınırlı ölçüde kullanılabilmektedir. Fizikokimyasal yöntemlerden biri olan zeolitlerin gıda ve yemlerde bulunan mikotoksinlerin detoksifikasyonlarında kullanımı son yıllarda önemli bir araştırma konusu haline gelmiştir (Var ve ark., 2008).

Zeolitler, her bir tetrahedronun köşelerinde bulunan dört oksijen atomunun, komşu tetrahedral kristaller ile paylaşılacağı bir şekilde birbirine bağlanmış $[\mathrm{AlO} 4]^{-5}$ ve $[\mathrm{SiO} 4]^{-4}$ 'ten yapılmış bir kristal yapıdan oluşur. Zeolit türlerinden olan Klinoptilolit yüksek absorpsiyon kapasitesi, katyon değişimi, kataliz ve dehidrasyon kapasiteleri ile en çok tercih edilen zeolit tipidir (Jha ve Singh, 2016). Mikotoksinlerin hayvan sağlığına etkisini minimize etmek amacıyla, doğal zeolitlerin (DZ) adsorblama özelliklerinden hayvan beslenmesinde yararlanıldığı bilinen bir gerçektir. Yapısı değiştirilmemiş (unmodified) bu mineraller Aflatoksinlerin adsorbsiyonunda etkin bir biçimde kullanılmaktadır. Bu modifiye edilmemiş minerallerin hidrofilik yüzeyleri, OTA gibi hidrofobik moleküller için zayıf adsorbanlar olarak kabul edilmektedir. Bununla birlikte, doğal montmorillonite ve klinoptilolitin yüzey özellikleri, organik ile basit iyon değişimi ile modifiye edilebilmektedir 
(Daković ve ark., 2003). Organo zeolitler, inorganik olarak değiştirilebilir katyonların, organik kuaterner amonyum veya piridinyum katyonları gibi organik katyonlarla değiştirildiği, böylece zeolitin yüzey özelliklerini hidrofilikten hidrofobik hale dönüştürüldüğü zeolit mineralleridir. Organozeolitlerin yapılandırılması esnasında, organik grupların zeolitlere adsorbsiyon işleminde, iki mekanizmanın baskın olduğu düşünülmektedir. Bunlardan ilki, yüzey aktif bileşik ile zeolitin katmanları arasında gerçekleşen iyon değişimi, ikincisi ise yüzey aktif bileşiğin uzun kuyrukları arasındaki hidrofobik etkileşimler yoluyla zeolite daha fazla katyon değişim özelliği sağlanmasıdır (Daković ve ark., 2003).

Zeolitlerin, yüksek özgül yüzey alanı ve yüksek iyon değiştirme kapasitesine sahip yapısal özellikleri nedeniyle iyon değiştirici malzemeler görevi gördükleri ve bu bağlamda sulu ortamdan metal iyonlarının uzaklaştırılmasında yaygın olarak kullanıldıkları bilinmektedir (Top ve Ülkü, 2004). Doğal ve modifiye zeolitlerin yüksek iyon değişim kapasitesi, katalitik ve adsorpsiyon özelliklerinin yanı sıra proses esnasındaki stabiliteleri nedeniyle, su (Margeta ve ark., 2013) ve atık su arıtma (Wasielewski ve ark., 2018), içme suyu sertliğinin giderilmesi (Bilgin ve Koç, 2013), kozmetik ve diğer sanayi türleri (Mercurio ve ark., 2019), gıda işleme ve tarım gibi yaşamın birçok alanında kullanılmalarını sağlar (Varga ve ark., 2010). Ayrıca, son yıllarda doğal zeolitlerden elde edilen gida takviyeleri sporcu beslenmesinde kullanılmaktadır (Lamprecht ve ark., 2015). Bununla birlikte, içeriğinde bulunan yüksek miktarda alüminyum nedeniyle doğal ve modifiye zeolitlerin, mide özsuyuna Aluminyum salınımı ve bağırsaklara kurşun salınımı gibi direkt insan tüketimine ilişkin konularda uygun olup olmadığına ilişkin soru işaretleri mevcuttur. Bu konu ile ilgili yapılan çalışmalar oldukça kısıtlı olup, yeni ve kapsamlı araştırmaların yapılması gerekmektedir.

Avrupa Birliği Gıda ve Yem için Hızlı Alarm Sistemi (the Rapid Alert System for Food and Feed. - RASFF) verileri incelendiğinde 1985'ten günümüze AB sınır kapılarından reddedilen üzüm parti sayısının 6 olduğu, bunun ise tamamının Türkiye menşeili üzüm suyu ürünleri olduğu görülmektedir (RASFF, 2020). Ancak üzüm suyu üreticilerimizin 2016 yllından itibaren bu sorunu çözdüğ̈̈, bu yıldan itibaren hiçbir şekilde limit değeri geçen ürün kaydı olmadı̆̆ belirlenmiştir. Üzüm suyu ve şarap üretiminde aktif karbon, bentonit gibi adsorban maddelerin üründen OTA giderimi için kullanıldığı yıllardan beri bilinmektedir. Bunun anlamı üzüm suyu üreticilerinin bu adsorbanları başarılı bir biçimde kullanarak üründe bulunabilecek OTA varlığına karşı etkili bir biçimde önlem aldığını göstermektedir.

Bu çalışmanın amacı, üzüm sularında Okratoksin A (OTA) giderilmesi amacıyla doğal zeolitklinoptilolitin ve oktadesil trimetil amonyum bromid ile adsorbsiyon özelliği geliştirilmiş organo zeolit- klinoptilolitin'in kullanılabilirliğinin araştırılmasıdır. 


\section{Materyal ve Metot}

\subsection{Materyal}

Araştırmada kullanılacak olan doğal zeolit- clinopitilotit yapıda olup, Manisa ili Gördes ilçesinde bulunan Gördes Madencilik A.Ş tarafından ücretsiz olarak temin edilmiştir. 100 er g'lık partiler halinde $100 \mu \mathrm{m}$ ve 1-3 mm çapında iki boyutta zeolit ile çalışılmıştır.

Araştırmaya konu olan beyaz üzüm suları piyasada satılan \%100 doğal üzüm suları olup Giresun il merkezinde bulunan marketlerden temin edilmiş, 5 L pastörize üzüm suyu satın alınarak stok üzüm suyu $+4{ }^{\circ} \mathrm{C}$ 'de depolanmıştır.

\subsection{Metod}

Araştırmada öncelikle doğal zeolitin (DZ) farklı koşullarda OTA adsorbsiyon kapasiteleri belirlenmiş, daha sonra bu zeolitlerin OTA adsorbsiyon yeteneklerinin geliştirilmesi amacıyla, oktadesil trimetil amonyum bromid ile yüzey modifikasyonu gerçekleştirilmiş, daha sonra da elde edilen uzun zincirli organo-zeolit/ modifiye zeolit (MZ) OTA adsorbsiyon kapasitesi belirlenmiştir. OTA adsorbsiyon verileri elde edildikten sonra, gıda numuneleri ile denemelere başlanmıştır. Pastörize üzüm sularına bilinen konsantrasyonda OTA ilave edilecek ve çeşitli şartlarda DZ ve MZ'in OTA adsorbsiyon oranları \% cinsinden ifade edilmiştir.

\subsubsection{Doğal Zeolitten Uzun Zincirli Organo-zeolit (ODTMA-Z) Sentezi}

Uzun zincirli organo-zeolit sentezi, DZ’in yüzey yapısının apolar karakterini arttırarak OTA çekim gücünü geliştirmek amacıyla yapılmıştır. Sentezleme işlemi Tomasevic-Canovic et al. (2003) tarafından önerilen metoda göre yapılmış, Oktadesil trimetil amonyum bromid (ODTMA) (Sigma Aldrich, Germany) ile DZ muamele edilerek uzun zincirli modifiye zeolit sentezi gerçekleştirilmiştir. Sentez işleminde 5 g $50 \mu \mathrm{m}$ ve 1-3 mm boyutunda iki farklı DZ, $100 \mu \mathrm{mol} .100 \mathrm{~g}^{-1}$ quarterner amonyum tuzuna eşdeğer miktarı ile hazırlanmış $100 \mathrm{~mL}$ ODTMA çözeltisi ile $50{ }^{\circ} \mathrm{C}$ 'de 15 dakika süre ile karıştırıcılı su banyosunda (Nüve ST30, Türkiye) muamele edilmiştir. Bu işlemin sonunda elde edilen MZ, filtre edilerek, saf su ile yıkanmıştır. Yıkama işlemine yıkama suyunda Brom iyonu kalmayana kadar devam edilmiştir. Brom iyonunun yıkama suyunda kalıp kalmadığının belirlenmesinde $0.1 \mathrm{~N}$ AgNO3 çözeltisi kullanılmıştır, yıkama işlemine yıkama suyunda $\operatorname{AgBr}(\mathrm{k})$ çökeltisi kalmayıncaya kadar devam edilmiş, yıkama işlemi bittikten sonra ise elde edilen $\mathrm{MZ}$ etüvde 
$60{ }^{\circ} \mathrm{C}$ 'de 5 saat kurutulmuştur. 4 faklı tip zeolit grubu oluşturulmuş ve oluşturulan doğal ve organo zeolitler aşağıdaki şekilde kodlanarak kullanılmıştır.

1- NT: $100 \mu \mathrm{m}$ boyutlu doğal zeolit (Normal toz form)

2- $\quad$ MT: $100 \mu \mathrm{m}$ boyutlu modifiye zeolit (Modifiye toz form)

3- $\quad$ CN: 1-3 mm boyutlu doğal zeolit (Normal form)

4- $\quad$ CM: 1-3 mm boyutlu modifiye zeolit (Modifiye form)

\subsubsection{Doğal Zeolitin Farklı Koşullarda OTA Adsorbsiyon Kapasitesinin Belirlenmesi}

\subsubsection{Sorbent Miktarının OTA Adsorbsiyonuna Etkisi}

Sorbent miktarının OTA adsorbsiyonuna etkisinin belirlenmeside Pasinli ve Henden (2013) tarafından önerilen metot kullanılmıştır. Bu amaçla, ilk olarak $0.05 \mathrm{~g}(\% 0.5), 0.1 \mathrm{~g}(1 \%), 0.25 \mathrm{~g}$ (\%2.5) ve 0.5 g (\%5) düzeylerinde DZ ve MZ’ler 15 mL’lik falkon tüplerine konulmuş, üzerine 10 mL 5 ve 10 ppb OTA içeren pH'1 3'e ayarlanmış tampon çözeltiler (0.1M Potasyum hidrojen fitalat (Merck, Almanya)+ 0.1 M HCL ile pH’1 3 e ayarlanmış tampon) ilave edilerek 30 dakika süresince oda sıcaklığında döner çalkalayıcı (250 rpm) ile karıştırılmıştır. Daha sonra, falkon tüpleri 5000g'de 10 dakika süreyle santrifüj edilmiştir.Üstte kalan sıvı faz atıldıktan sonra adsorban maddeye $10 \mathrm{~mL}$ saf su ilave edilerek 15 sn süre ile vorteks (Dragonlab, Çin) kullanılarak karıştırılmış ve daha sonra tekrar 5000g'de 5 dakika süreyle santrifüj edilmiştir. Bu işlem 2 defa daha tekrar edilerek, adsorbandda kalabilecek olan tampon çözelti, su ile yıkanarak uzaklaştırılmıştır. Yıkama işleminden sonra, OTA'yı adsorban maddeden geri almak amaciyla her bir falkon tüpüne $10 \mathrm{~mL}$ metanol (HPLC grade, Merck, Darmstadt, Germany) ilave edilmiş, adsorban ve metanol içeren tüpler döner çalkalayıcı (250 rpm) ile 30 dakika süresince karıştırılmıştır. Daha sonra tüpler yeniden 5000 g'de 5 dakika süreyle santrifüj edilmiş, elde edilen üstte kalan sıvı faz temiz bir falkon tüpüne aktarılmıştır. Azot altında metanolün tamam $40^{\circ} \mathrm{C}$ 'de kuruluğa kadar uçurulduktan sonra tüplere mobil faz (MeCN: H2O: Asetik asit, 98:98:2) ilave edilmiş, tüpler 10 sn süre ile vorteks ile karıştırılmıştır. Adsorbandan geri alınan OTA ve mobil faz $0.45 \mu \mathrm{m}$ 'lik şırınga filtreden geçirilerek $2 \mathrm{~mL}$ 'lik viallere alınmış; OTA miktarı HPLC'de standart pikler ile karşılaştırılarak belirlenmiştir. Denemeler üçer tekerrür şeklinde gerçekleştirilmiştir. 


\subsubsection{Karıştırma Sıcaklığının OTA Adsorbsiyonuna Etkisi}

Karıştırma sıcaklığının OTA adsorbsiyonuna etkisinin belirlenmesi amacıyla Pasinli ve Henden (2013)'in önerdiği metod modifiye edilerek kullanılmıştır. 10 mL 10 ppb OTA içeren pH'1 3'e ayarlanmış tampon çözeltiler 25,30 ve $45^{\circ} C^{\prime}$ ye 1 sıtılmış ve daha sonra 0.5 g (5\%) DZ ve MZ'ler ilave edilerek 30 dakika süresince karıştırılmıştır. Bu sürenin sonunda adsorbanda tutuklanan OTA ekstrakt edilerek HPLC’ de analiz edilmiştir.

\subsubsection{3. İşlem Süresinin OTA Adsorbsiyonuna Etkisi}

İşlem süresinin OTA adsorbsiyonuna etkisinin belirlenmesi amacıyla, 5 ve 10 ng.mL ${ }^{-1}$ OTA içeren pH'1 3'e ayarlanmış 10 mL'lik tampon çözeltilere 0.5 g (5\%) DZ ve MZ'ler ilave edilerek 30, 60, 90 ve 120 dakika süresince oda sıcaklığında döner çalkalayıcıile karıştırılmıştır. Belirtilen sürelerin sonunda adsorban maddelerde tutuklanan OTA miktarı HPLC'de analiz edilmiştir. Denemeler üçer tekerrür şeklinde gerçekleştirilmiştir.

\subsection{3. Üzüm Suyu Numune Denemeleri}

Araştırmada, üzüm sularındaki OTA’nın adsorbsiyonuna DZ ve MZ adsorbanlarının etkisinin belirlenmesi amacıyla, $100 \mathrm{~mL}$ OTA içermeyen temiz üzüm suyuna $10 \mathrm{ppb}$ düzeyinde OTA ilave edilerek, OTA içeren stok üzüm suyu elde edilmiş, stok çözeltiden $10 \mathrm{ml}$ alınarak 5\% adsorban içeren falkon tüplerine transfer edilmiştir. Tampon çözelti denemelerinde, tüm zeolit tipleri için maksimum adsorbsiyonun belirlendiği miktar, karıştırma sıcaklığı ve sürenin sırasıyla $5 \%$ adsorban, $45^{\circ} \mathrm{C}$ ve 120 dk olduğu görülmüştür. Ancak adsorbsiyon ortamı artık tampon değil de gerçek gıda ortamı olduğundan $10 \mathrm{ng} \cdot \mathrm{mL}^{-1}$ OTA içeren üzüm suyuna 5\% oranında zeolit ilave edilmiş, 30 dakika sürenin yetersiz olabileceği düşünülerek, 60,90 ve $120 \mathrm{dk}$ süresince $45^{\circ} \mathrm{C}$ 'de karıştırma işlemi gerçekleştirilmiştir. Belirtilen sürelerin sonunda adsorban maddelerde tutuklanan OTA miktarı HPLC'de analiz edilmiştir.

\subsubsection{HPLC Şartları}

Örneklerden elde edilen ekstraktların kantitatif analizinde Agilent 1260 Infinity Series (Agilent Technologies, CA, United States) HPLC cihazı ve buna bağlı çalışan G1321A florasan detektör (FLD), G1311B pompa, a G1329 otoörnekleyici ve G4225A degazer kullanılmıştır. Örnek ekstraktlarından OTA'nın belirlenmesi için kullanılacak olan mobil faz izokratik olarak 
düzenlenmiştir. Kromatografik koşullar için $3 \mu \mathrm{m}$ gözenek ölçüsüne sahip sahip ACE ODS2TM C18-300 (Aberdeen, Scotland) kolon yine 3 m gözenek ölçüsüne sahip yardımcı kolon ile birlikte kullanılmıştır. Mobil faz olarak MeCN:H2O:Asetik asit (98: 2 (h/h) ) kullanılmış, akış hızı 1m1/dk, kolon firın sıcaklığ $30^{\circ} \mathrm{C}$, FLD dedektör uyarma dalga boyu 333nm ve Emisyon dalga boyu $460 \mathrm{~nm}$ olarak seçilmiştir. Enjeksiyon hacmi $100 \mu$ L'dir. OTA standardı olarak analitik konsantrasyonu 10 $\mu \mathrm{g} . \mathrm{mL}^{-1}$ konsantrasyonlu standart çözelti ( $1 \mathrm{ml}$, Biopure, Romerlab, Tulin, Austria) kullanılmıştır. Stok standarttan $1000 \mu \mathrm{l}$ temiz bir viale aktarılarak üzerine $4000 \mu \mathrm{L}$ HPLC dereceli metanol (Merck, Darmstadt/Germany) ilave edilmiş böylece $2 \mu \mathrm{g} \cdot \mathrm{mL}^{-1}$ konsantrasyonlu stok çözelti elde edilmiştir. Bu stok çözeltiden 0.5, 1.0, 2.0, 4.0, 8.0, 10 ve 20 ng.mL $\mathrm{mL}^{-1}$ konsantrasyonda standart çözeltiler hazırlanmıştır. Bu çözeltiler sabit akış hızında $\left(1 \mathrm{~mL} \cdot \mathrm{dk}^{-1}\right)$ HPLC cihazına verilerek kalibrasyon eğrisi oluşturulmuştur. Belirtilen şartlar eşliğinde elde edilen kalibrasyon eğrisi doğrusaldır $\left(r^{2}=0.9999\right)$.

\subsection{5. İstatistik Analiz}

Denemeler 3 tekerrürlü gerçekleştirilmiş olup, elde edilen zeolit tipleri arasındaki farklılıklar SPSS 22.0 paket programı kullanılarak TUKEY çoklu karşılaştırma testi ile 95\% güven aralığında değerlendirilmiştir. Tampon çözetilere ilave edilen adsorban miktarı, sıcaklık, süre gibi faktörlerin her bir zeolit tipi için farklılıkları belirlenmiş, miktar-sıcaklık, miktar-süre varyasyonlarının zeolit çeşitlerinin OTA alıkoyma düzeylerine ortak etkileri de belirlenmiştir. Araştırma sonuçların ait grafikler ve doğrusal regresyon analizleri Sigmaplot 11.0 paket programı kullanılarak gerçekleştirilmiştir.

\section{Bulgular ve Tartışma}

\subsection{Sorbent Miktarının OTA Adsorbsiyonuna Etkisi}

Çalışmanın bu aşamasında, 5 ng ve 10 ng.mL ${ }^{-1}$ OTA içeren pH'ı 3'e ayarlanmış tamponlara $0.5 \%, 1 \%, 2.5 \%$ ve $5 \%$ oranlarında NT, MT, CN, CM adsorbanları ilave edilmiş, 30 dakika oda sıcaklığında karıştırma süresi sonunda adsorbanlar tarafından tutuklanan OTA miktarları (\%Geri alma yüzdesi) Tablo 1 ve Tablo 2’de, sonuçlara ait grafikler ise Şekil 1a ve 1b. 'de gösterilmiştir. Araştırma sonuçlarına göre 30 dakika karıştırma sonunda tampon çözeltiye ilave edilen adsorban miktarı arttıkça, adsorbsiyon işlemi sonunda elde edilen OTA geri kazanım oranı tüm adsorban çeşitleri için önemli derecede $(p<0.05)$ artmakta, bununla birlikte, tampon çözeltide OTA konsantrasyonu arttıkça adsorbsiyon geri kazanım oranı azalmaktadır. 
Tablo 1. Farklı miktarlarda zeolit ilave edilmiş 5 ng. $\mathrm{mL}^{-1}$ OTA içeren tampon çözelti için adsorbanlardan geri alınan OTA düzeyleri (\%)

\begin{tabular}{|c|c|c|c|c|}
\hline \multirow[b]{2}{*}{ Zeolit tipi } & \multicolumn{4}{|c|}{ Tampona ilave edilen adsorban miktarı (\%) } \\
\hline & 0.5 & 1 & 2.5 & 5 \\
\hline $\mathbf{C N}$ & $5.7^{\mathrm{aA}} \pm 0.62$ & $9.0^{\mathrm{aAB}} \pm 1.09$ & $13.6^{\mathrm{aBC}} \pm 1.1$ & $19.0^{\mathrm{aC}} \pm 6.54$ \\
\hline CM & $5.8^{\mathrm{aA}} \pm 0.76$ & $13.6^{\mathrm{aB}} \pm 1.82$ & $20.8^{\mathrm{bC}} \pm 3.99$ & $29.0^{\mathrm{aD}} \pm 0.40$ \\
\hline NT & $22.8^{\mathrm{bA}} \pm 0.40$ & $34.4^{\mathrm{bB}} \pm 3.63$ & $36.5^{\mathrm{cB}} \pm 0.72$ & $42.9^{\mathrm{bC}} \pm 8.38$ \\
\hline MT & $43.7^{\mathrm{cA}} \pm 4.36$ & $50.0^{\mathrm{CAB}} \pm 4.17$ & $53.3^{\mathrm{dB}} \pm 2.91$ & $65.8^{\mathrm{cC}} \pm 3.64$ \\
\hline
\end{tabular}

*: Sonuçlar 3 tekerrür ortalaması \pm Standart Sapma şeklinde verilmiştir.

aA:Küçük harfler sütunlar arası farklılıkları, büyük harfler satırlar arası farklılıkları ifade etmektedir.

Daković ve ark. (2003) tarafından yapılan bir çalışmada, farklı konsantrasyonlarda ODTMA ile değiştirilmiş doğal zeolitlerin OTA adsobsiyon kapasitelerinin kullanılan adsorban miktarı arttıkça arttığını belirlemişlerdir.

Benzer durum zeolit dışındaki farklı adsorbanlar için de geçerlidir. Var ve ark. (2008) fosfat tamponu (PBS) ve beyaz şaraptan OTA uzaklaştırmak amacıyla farklı miktarlarda aktif karbon ve bentonit uygulaması gerçekleştirmiş, her $5 \mathrm{~mL}$ 'lik OTA içeren PBS ve beyaz şarap örneğine $0.2,0.4$ ve $1 \mathrm{mg} \mathrm{mL}^{-1}$ düzeyinde adsorban ilavesi gerçekleştirilerek tüpler 10 sn vorteks ile karıştırılmış, oda sıcaklığında bekletilen tüplerin 0.saat, 4.saat ve 24. saatlerde adsorbsiyon yüzdesi hesaplanmıştır. Araştırıcılar PBS çözeltileri içindeki adsorban miktarının artmasının adsorbsiyon yüzdesini arttırdığı sonucuna varmışlardır. Buna göre adsorban madde miktarı arttıkça adsorbsiyon kapasitesi artmaktadır. Araştırmadan elde edilen bulgular bu sonuçlarla örtüşmektedir.

Tampon çözeltiye ilave edilen adsorban miktarının farklı OTA konsantrasyonlarında adsorbsiyon düzeylerine ait doğrusal regresyon analiz sonuçları Şekil 1'de gösterilmiştir. 5 ng.mL ${ }^{-1}$ ve OTA içeren tampon çözeltilere ilave edilen adsorban miktarının zeolitlerin OTA adsorbsiyonuna etkisine ait determinasyon katsayılarının $\left(\mathrm{R}^{2}\right) \mathrm{NT}$ örneği hariç 0.8'den büyük olduğu belirlenmiştir. Bu da değişkenler arasında iyi bir korelasyonun olduğunu göstermekte ve 5 ng.mL $\mathrm{mL}^{-1}$ OTA içeren tampon çözeltilerde adsorban miktarı arttıkça, adsorbsiyon düzeyinin arttığına işaret etmektedir. Farklı miktarda zeolit ilave edilmiş 10 ng.mL $\mathrm{mL}^{-1}$ OTA içeren tampon çözeltilerin determinasyon katsayıları incelendiğinde ise, en yüksek adsorbsiyon değerine ulaşılmasına rağmen, 0.8 'den düşük $\mathrm{R}^{2}$ değeri MT örneğinde tespit edilmiş, diğer tüm örneklerin $\mathrm{R}^{2}$ değerlerinin 0.8 'den büyük olduğu ancak 30 dakika karıştırma süresinin maksimum OTA adsorbsiyonu için yeterli olmadığı belirlenmiştir. 
Tablo 2. Farklı miktarlarda zeolit ilave edilmiş 10 ng. $\mathrm{mL}^{-1}$ OTA içeren tampon çözelti için adsorbanlardan geri alınan OTA düzeyleri (\%)

Tampona ilave edilen adsorban miktarı (\%)

\begin{tabular}{lcccc}
\hline Zeolit tipi & $\mathbf{0 . 5}$ & $\mathbf{1}$ & 2.5 & $\mathbf{5}$ \\
\hline $\mathbf{C N}$ & $2.3^{\mathrm{aA}} \pm 1.28$ & $3.4^{\mathrm{aA}} \pm 0.33$ & $17.4^{\mathrm{a}^{\mathrm{B}}} \pm 0.38$ & $21.04^{\mathrm{aC}} \pm 1.47$ \\
$\mathbf{C M}$ & $5.4^{\mathrm{bA}} \pm 0.36$ & $8.8^{\mathrm{bA}} \pm 2.72$ & $22.0^{\mathrm{aB}} \pm 4.24$ & $26.8^{\mathrm{bC}_{ \pm}} \pm .35$ \\
$\mathbf{N T}$ & $15.8^{\mathrm{cA}} \pm 1.11$ & $21.4^{\mathrm{cB}} \pm 0.26$ & $30.3^{\mathrm{bC}} \pm 1.81$ & $39.1^{\mathrm{CD}_{ \pm}} \pm 0.33$ \\
$\mathbf{M T}$ & $26.2^{\mathrm{dA}} \pm 0.40$ & $29.0^{\mathrm{dA}} \pm 3.60$ & $43.2^{\mathrm{cB}} \pm 5.45$ & $45.7^{\mathrm{dB}} \pm 4.55$ \\
\hline
\end{tabular}

*: Sonuçlar 3 tekerrür ortalaması \pm Standart Sapma şeklinde verilmiştir.

aA:Küçük harfler sütunlar arası farklılıkları, büyük harfler satırlar arası farklılıkları ifade etmektedir.

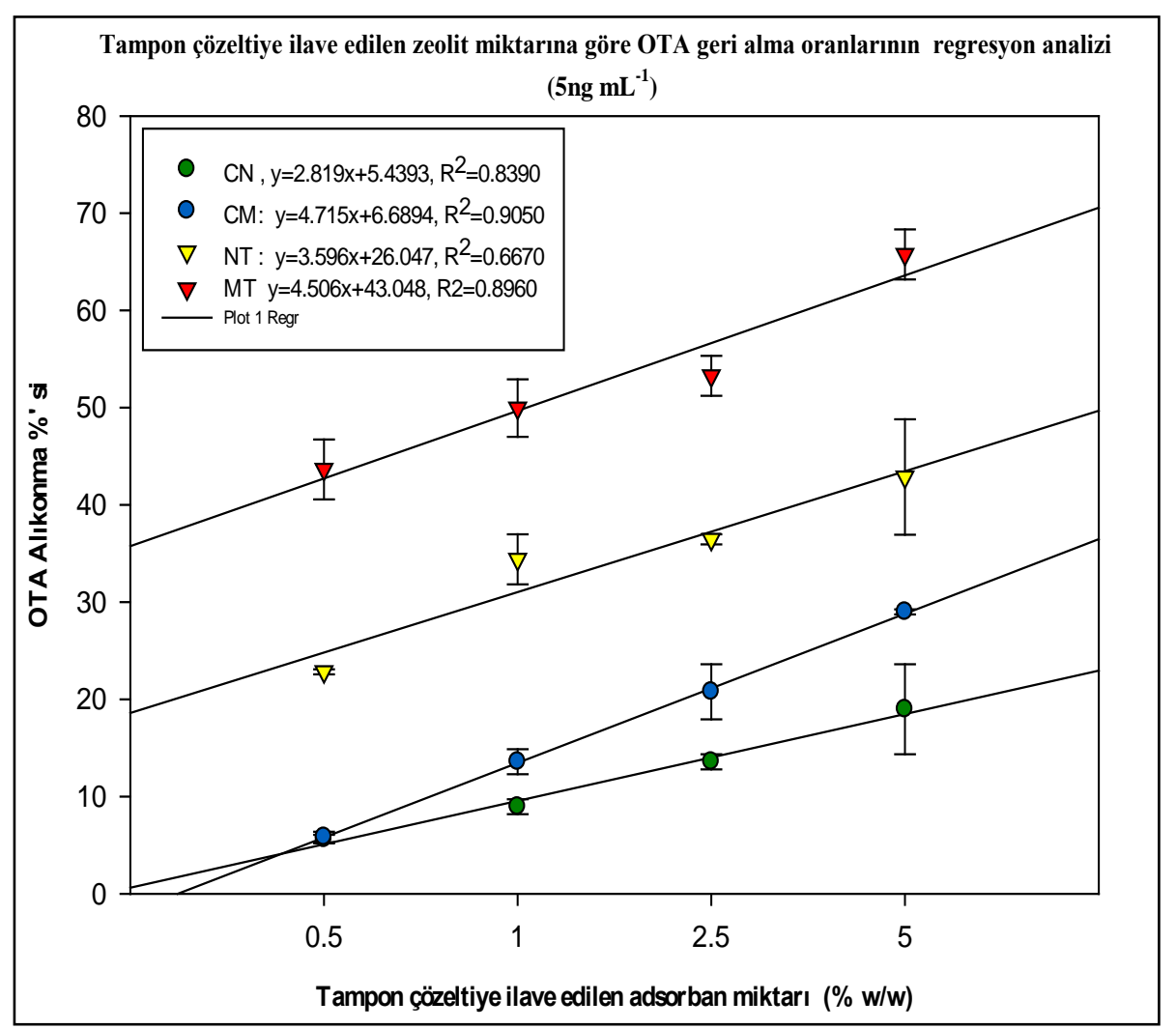

Şekil 1a. 5 ng.mL ${ }^{-1}$ zeolit ilave edilmiş OTA içeren tampon çözelti için geri alma yüzdelerine ait regresyon analiz sonuçları (Hata çubukları standart hata olarak verilmiştir) 


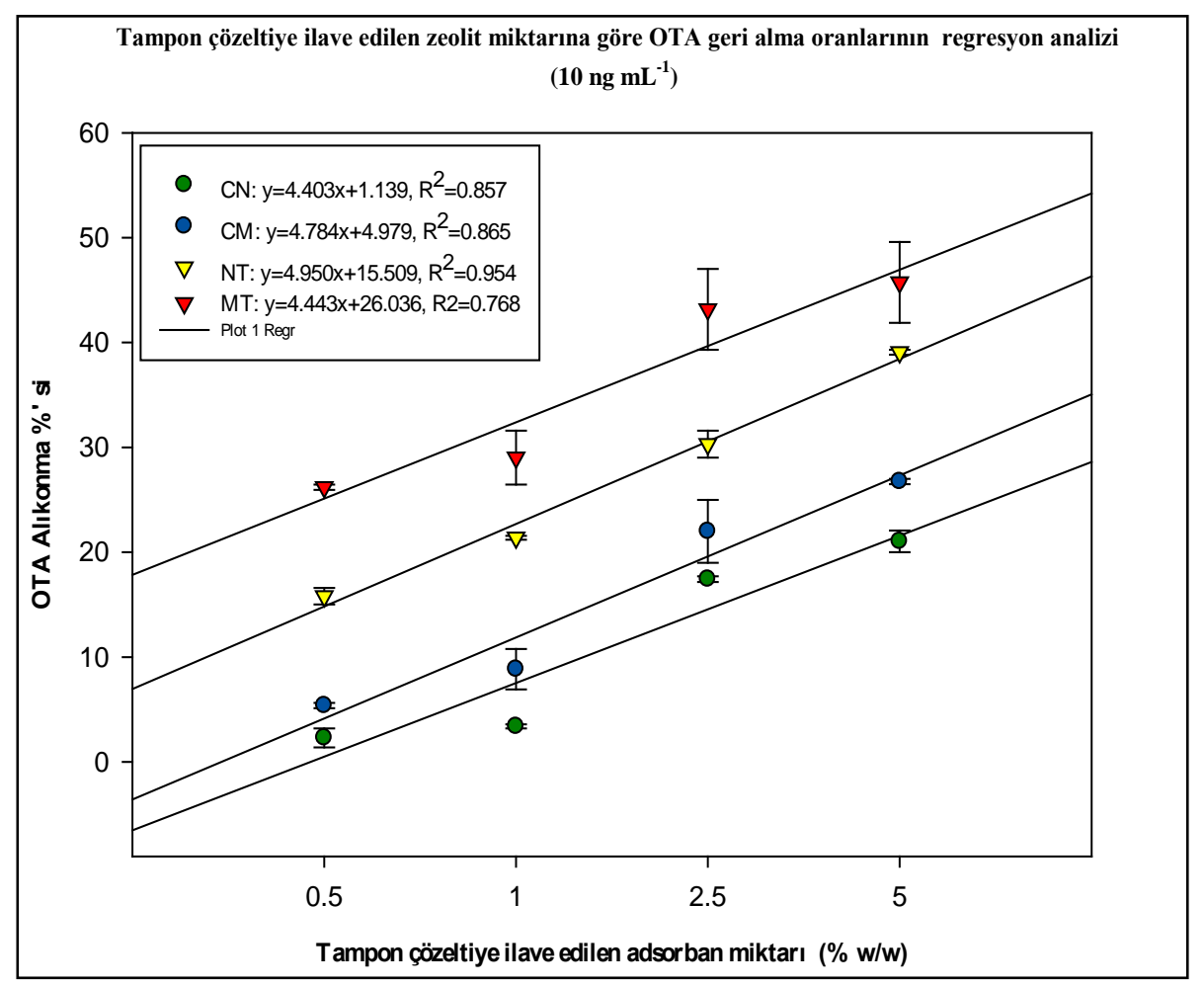

Şekil 1b. 5 ng.mL ${ }^{-1}$ zeolit ilave edilmiş OTA içeren tampon çözelti için geri alma yüzdelerine ait regresyon analiz sonuçları (Hata çubukları standart hata olarak verilmiştir)

Araştırma sonuçları, boyut farklılığg ve yüzey modifikasyon işleminin de adsorbsiyon işleminde önemli faktörler olduğunu ortaya koymuştur. Genel olarak toz formundaki adsorban iri boyutlu olanlara göre OTA'yı çok daha fazla $(\mathrm{p}<0.05)$ miktarda adsorbe etmiştir. Bunun en büyük nedeni toz formunda adsorbanların yüzey alanının oldukça büyük olması, çözeltiyle etkileşim kapasitesinin daha iyi olmasıdır. Yüzey modifikasyon işleminin OTA adsorbsiyon kapasitesini önemli ölçüde arttırdığı $(\mathrm{p}<0.05)$ gözlenmiştir. 5 ng.mL ${ }^{-1}$ OTA ve 5\% adsorban içeren tampon çözeltilerde elde edilen maksimum \%adsorbsiyon oranı $65.8 \% \pm 3.64$ ile MT örneğinde, 10 ng.mL ${ }^{-1}$ OTA ve 5\% adsorban içeren tampon çözeltilerde ise $45.7 \% \pm 4.55$ ile yine MT örneklerinde gerçekleşmiştir. 1-3 mm boyutundaki zeolitlerde ise yüzey modifikasyon işlemiyle elde edilen organozeolitlerin daha yüksek adsorbsiyon gerçekleştirdikleri belirlenmesine rağmen, toz formundaki zeolitlere göre yüzey alanı daha küçük olduğundan adsorbsiyon daha sınırlı gerçekleşmiştir. Bu örneklerde adsorbsiyon oranı $\mathrm{CN}$ ve $\mathrm{CM}$ örnekleri için sırasıyla $21.04 \% \pm 1.47$ ve $26.8 \% \pm 0.35$ düzeyinde gerçekleşmiştir. $5 \mathrm{ng}$ ng.mL ${ }^{-1}$ OTA ilave edilmiş tampon çözeltilerde yüzey modifikasyon işleminin 1-3 mm boyutunda zeolitler için, CM örneği hariç, ilave edilen tüm düzeylerde, tampon çözeltilerin OTA adsorbsiyon düzeyinde anlamlı bir fark yaratmadığı ( $\mathrm{p}>0.05)$ gözlenmiştir. Çalışmanın bu aşamasından sonra, elde edilen veriler 1şığında, \%5 adsorbsiyon miktarı sabit tutularak diğer parametrelerin çalışılmasına devam edilmiştir. 


\subsection{Karıştırma Sıcaklığının OTA Adsorbsiyonuna Etkisi}

Farklı karıştırma sıcaklıklarının adsorbanlar tarafından tutuklanan OTA miktarları (\%Geri alma düzeyi) üzerine etkisi Tablo 3 ve Tablo 4’te gösterilmiştir. Araştırma sonuçları, karıştırma sıcaklığı arrtıkça ile tüm zeolit tipleri için OTA adsorbsiyon oranının önemli düzeyde $\operatorname{arttığını~}(\mathrm{p}<0.05)$ göstermiştir. Bu durum difüzyon hızının artması ile birlikte zeolit boşluklarına sıvı girişi ve bunun sonucu olarak OTA etkileşiminin artması şeklinde açıklanabilir.

Tablo 3. 5ng.mL ${ }^{-1}$ OTA ve 5\% zeolit içeren tampon çözeltilerde sıcaklığa bağlı OTA geri alma düzeyleri (\%)

\begin{tabular}{ccccc}
\hline & \multicolumn{4}{c}{ Adsorban Tipi } \\
\hline Sicaklık $\left({ }^{\circ} \mathbf{C}\right)$ & $\mathbf{C N}$ & $\mathbf{C M}$ & $\mathbf{N T}$ & $\mathbf{M T}$ \\
\hline $\mathbf{2 5}$ & $19.00^{\mathrm{aA}} \pm 6.54$ & $29.00^{\mathrm{aB}} \pm 0.40$ & $42.90^{\mathrm{aC}} \pm 8.38$ & $65.80^{\mathrm{aD}} \pm 3.64$ \\
$\mathbf{3 0}$ & $55.48^{\mathrm{bA}} \pm 3.64$ & $89.00^{\mathrm{bB}} \pm 7.02$ & $97.00^{\mathrm{bC}} \pm 2.82$ & $100.00^{\mathrm{bC}} \pm 0.0$ \\
$\mathbf{4 5}$ & $58.05^{\mathrm{bA}} \pm 7.27$ & $99.5^{\mathrm{cB}} \pm 2.12$ & $100.00^{\mathrm{bB}} \pm 0.0$ & $100.00^{\mathrm{bB}_{ \pm}} \pm 0.0$ \\
\hline
\end{tabular}

*: Sonuçlar 3 tekerrür ortalaması \pm Standart Sapma şeklinde verilmiştir.

aA:Küçük harfler sütunlar arası farklılıkları, büyük harfler satırlar arası farklılıkları ifade etmektedir.

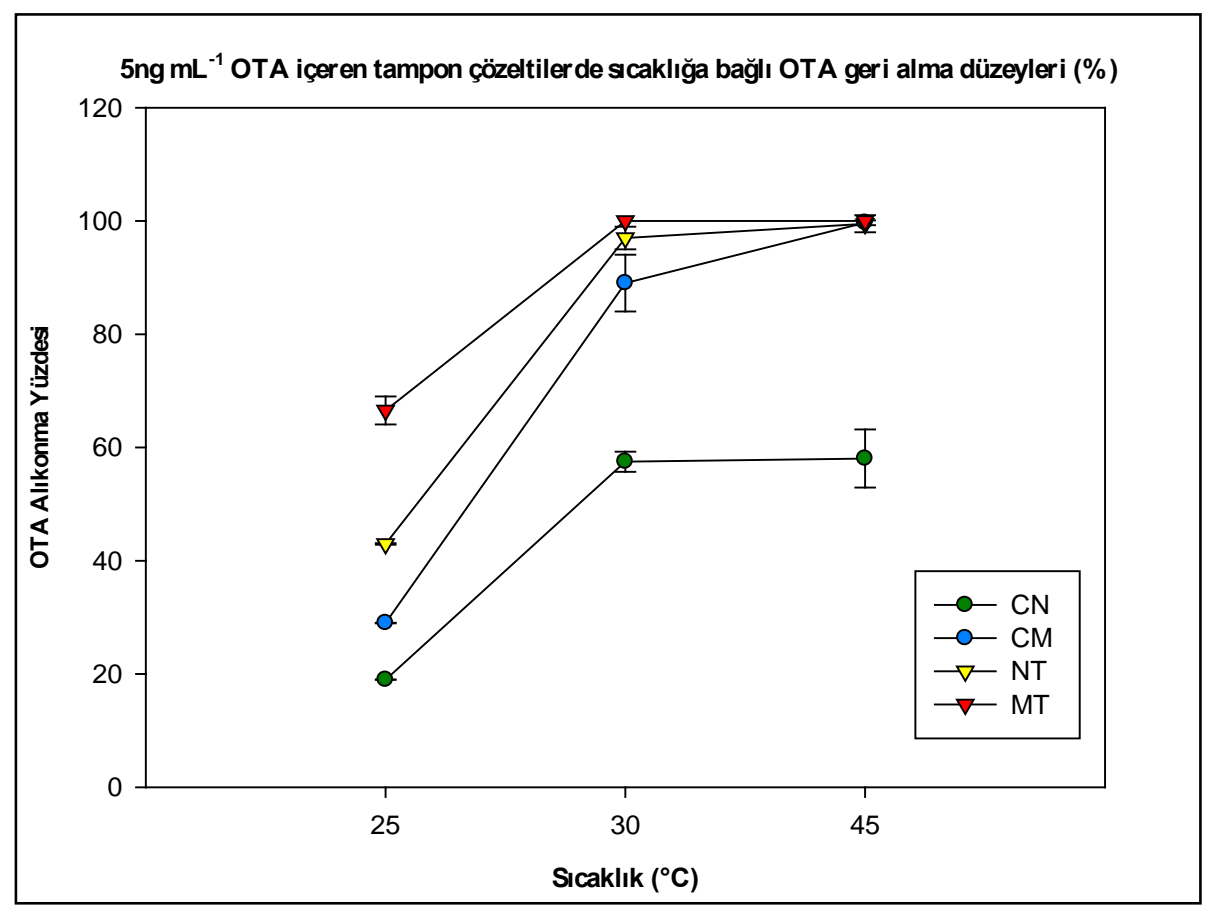

Şekil 2. 5\% Zeolit içeren tampon çözeltilerde sıcaklığa bağlı OTA geri alma düzeyleri

Literatürde sıcaklığın OTA adsorbsiyonuna etkisi ile ilgili herhangi bir çalışmaya rastlanmamıştır. Bununla birlikte Pasinli ve Henden (2013) DZ ve MZ adsorbanların Zearelenon adsorbsiyonu üzerine, karıştırma sıcaklığının etkisi olmadığını bildirmiştir. Araştırma sonuçları bu çalışmadan 
farklı çıkmıştır. 5 ng.mL ${ }^{-1}$ OTA içeren tampon çözeltiler için 30 dakika karıştırma süresi sonucunda 1-3 mm boyutundaki $\mathrm{CN}$ ve $\mathrm{CM}$ örneklerinde en yüksek adsorbsiyon düzeyleri $45^{\circ} \mathrm{C}$ gerçekleşmiş (Şekil 2), modifikasyon işleminin OTA adsorbsiyonunun önemli ölçüde $\operatorname{arttırdığ1~}(\mathrm{p}<0.05)$ belirlenmiştir. Yüzey modifikasyonu, $100 \mu \mathrm{m}$ boyutlu zeolit örnekleri için daha düşük sıcaklıklarda maksimum OTA adsorbsiyonuna ulaşılmasına olanak sağlamıştır (Şekil 3).

Tablo 4. 10ng.mL ${ }^{-1}$ OTA ve 5\% zeolit içeren tampon çözeltilerde sıcaklığa bağlı OTA geri alma düzeyleri (\%)

\begin{tabular}{ccccc}
\hline & \multicolumn{4}{c}{ Adsorban Tipi } \\
\hline Sicaklık $\left({ }^{\circ} \mathbf{C}\right)$ & $\mathbf{C N}$ & $\mathbf{C M}$ & $\mathbf{N T}$ & $\mathbf{M T}$ \\
\hline $\mathbf{2 5}$ & $21.04^{\mathrm{aA}} \pm 1.47$ & $26.8^{\mathrm{aB}} \pm 0.35$ & $39.1^{\mathrm{aC}} \pm 0.33$ & $45.7^{\mathrm{aD}_{ \pm}} \pm 4.55$ \\
$\mathbf{3 0}$ & $51.00^{\mathrm{bA}} \pm 1.41$ & $62.50^{\mathrm{bAB}} \pm 3.53$ & $58.00^{\mathrm{bB}} \pm 1.22$ & $76.50^{\mathrm{bC}} \pm 2.12$ \\
$\mathbf{4 5}$ & $62.00^{\mathrm{cA}} \pm 5.65$ & $75.50^{\mathrm{cB}} \pm 2.47$ & $76.25^{\mathrm{cB}^{\mathrm{B}}} \pm 2.47$ & $89.50^{\mathrm{cC}} \pm 4.95$ \\
\hline
\end{tabular}

*: Sonuçlar 3 tekerrür ortalaması \pm Standart Sapma şeklinde verilmiştir.

aA:Küçük harfler sütunlar arası farklılıkları, büyük harfler satırlar arası farklılıkları ifade etmektedir.

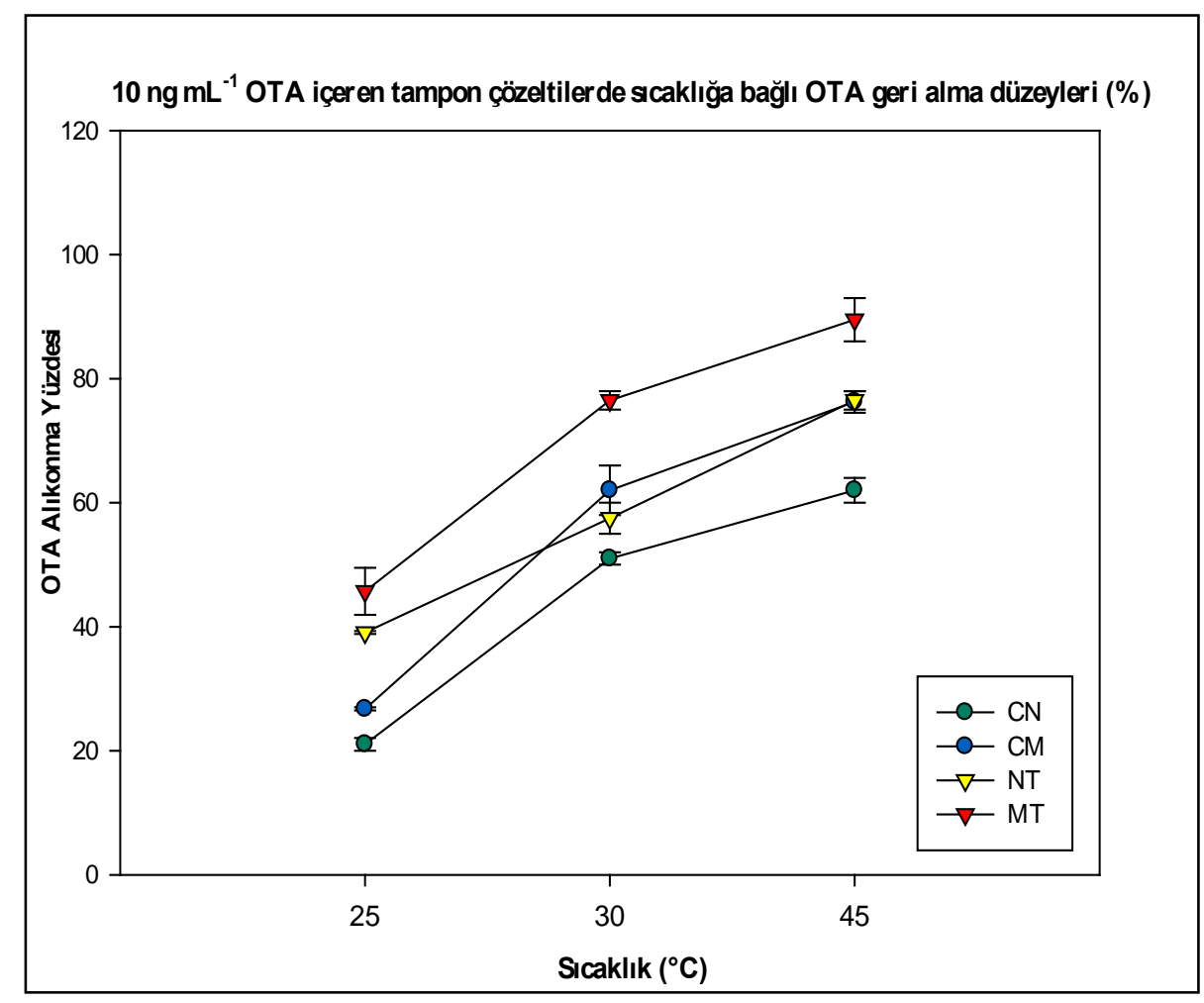

Şekil 3. 5\% Zeolit içeren tampon çözeltilerde sıcaklığa bağlı OTA geri alma düzeyleri

Karıştırma sıcaklığının ve tampon çözeltiye ilave edilen OTA miktarının doğal ve modifiye zeolit tiplerinin OTA alıkoyma düzeylerine ortak etkisi Şekil 4'te gösterilmiştir. Buna göre, tampon çözeltiye ilave edilen OTA miktarı arttıça, tüm zeolit tiplerinde OTA adsorbsiyon kapasitesinin 
azaldığı, ancak karıştırma sıcaklığının adsorbsiyon kapasitesini olumlu yönde etkilediği görülmektedir. Yüzey modifikasyonu uygulanmamış ve 1-3 mm boyutundaki CN örneklerinin OTA adsorbsiyon kapasitesinin hem 5 hem de 10 ng.mL -1 $^{-1}$ OTA içeren tampon çözeltiler için oldukça düşük düzeyde olduğu belirlenmiştir. ODTMA ile DZ’lerde gerçekleştirilen modifikasyon işleminin çalışmanın bu kısmında da etkili olduğu görülmektedir. En yüksek OTA adsorbsiyon miktarlarının hem 5 hem de 10 ng.mL ${ }^{-1}$ OTA içeren tampon çözeltiler için MT örneklerinde olduğu belirlenmiştir. Tampon çözeltideki OTA konsantrasyonun arttırılması adsorbsiyon düzeyinde azalmaya neden olmuş olsa da, özellikle yüzey modifikasyonu uygulanan zeolitlerin tampon çözeltideki OTA’y1 önemli düzeyde alıkoyabildiği görülmektedir.
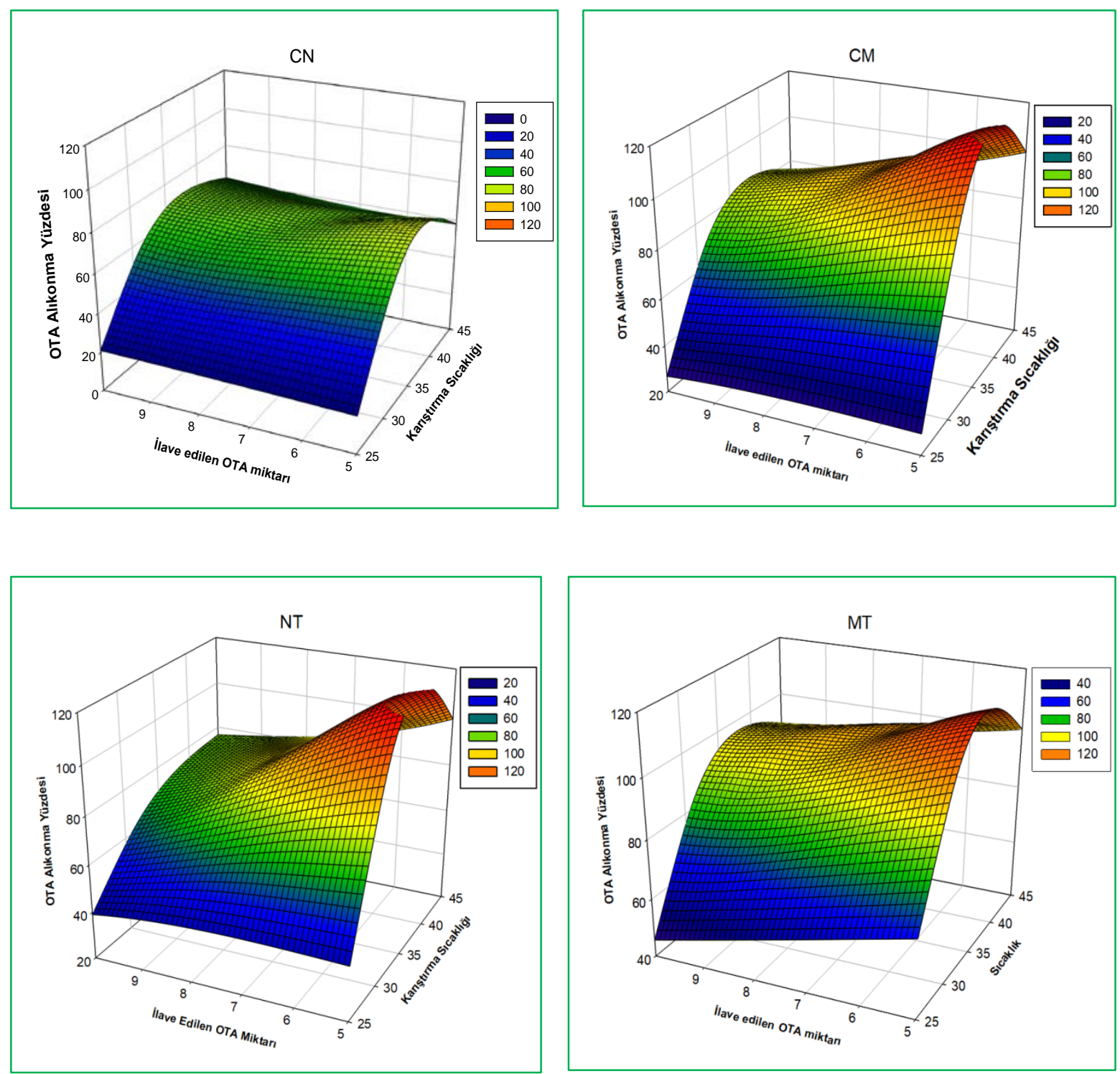

Şekil 4. Doğal ve modifiye zeolitlerin OTA alıkoyma düzeylerine tampon çözeltiye ilave edilen OTA miktarının ve sıcaklığın ortak etkisi. CN: 1-3 mm boyutlu doğal zeolit (Normal form); CM: 1-3 mm boyutlu modifiye zeolit (Modifiye form); NT: $100 \mu \mathrm{m}$ boyutlu doğal zeolit (Normal toz form); MT: $100 \mu \mathrm{m}$ boyutlu modifiye zeolit (Modifiye toz form) 


\section{3. İşlem Süresinin OTA Adsorbsiyonuna Etkisi}

Farklı işlem sürelerinin adsorbanlar tarafından tutuklanan OTA miktarları (\%Geri alma düzeyi) üzerine etkisi Tablo 5 ve Tablo 6’da gösterilmiştir.

Araştırma sonuçlarına göre, karıştırma süresinin artması adsorbsiyon miktarını tüm örnekler için önemli düzeyde $(\mathrm{p}<0.05)$ arttırmıştır. Yüzey modifikasyon işleminin $100 \%$ adsorbsiyona ulaşmayı hızlandırdığı görülmektedir (Şekil 5). Adsorban yüzey alanı daha büyük olan NT ve MT örnekleri karşılaştırıldığında, yüzey modifikasyonu yapılmış toz formundaki zeolitin 60 dakika karıştırma sonunda 100\% adsorbsiyona ulaştığı, 100\% adsorbsiyona ulaşmak için bu sürenin toz formundaki normal zeolit için 90 dakika olduğu belirlenmiştir.

Tablo 5.5 ng.mL $\mathrm{mL}^{-1}$ OTA ve $5 \%$ zeolit içeren tampon çözeltilerde karıştırma süresine bağlı OTA geri alma düzeyleri (\%)

\begin{tabular}{ccccc}
\hline & \multicolumn{4}{c}{ Adsorban Tipi } \\
\hline Karıștırma Süresi (dk) & $\mathbf{C N}$ & $\mathbf{C M}$ & $\mathbf{N T}$ & $\mathbf{M T}$ \\
\hline $\mathbf{3 0}$ & $18.98^{\mathrm{aA}} \pm 6.54$ & $29.00^{\mathrm{aA}} \pm 0.40$ & $42.87^{\mathrm{ab}^{\mathrm{B}}} \pm 8.38$ & $65.77^{\mathrm{aC}} \pm 3.64$ \\
$\mathbf{6 0}$ & $24.43^{\mathrm{aA}} \pm 1.89$ & $76.89^{\mathrm{bB}} \pm 2.45$ & $83.76^{\mathrm{bB}} \pm 14.53$ & $100.00^{\mathrm{bC}} \pm 0.00$ \\
$\mathbf{9 0}$ & $41.44^{\mathrm{bA}} \pm 1.22$ & $90.37^{\mathrm{cB}} \pm 2.07$ & $100.00^{\mathrm{cC}} \pm 3.53$ & $100.00^{\mathrm{bC}} \pm 0.00$ \\
$\mathbf{1 2 0}$ & $56.00^{\mathrm{cA}} \pm 1.45$ & $93.71^{\mathrm{dB}} \pm 1.00$ & $100.00^{\mathrm{cC}} \pm 0.00$ & $100.00^{\mathrm{bC}} \pm 0.00$ \\
\hline
\end{tabular}

*: Sonuçlar 3 tekerrür ortalaması \pm Standart Sapma şeklinde verilmiştir.

aA:Küçük harfler sütunlar arası farklılıkları, büyük harfler satırlar arası farklılıkları ifade etmektedir.

Daha büyük boyutlu olan (1-3 mm) normal ve modifiye zeolitlerde ise (CN ve CM) 120 dakika sonunda 100\% adsorbsiyona ulaşılamamıştır. Ancak bu örnekler için de yüzey modifikasyonu yapılmış örneklerde daha yüksek oranda $(\mathrm{p}<0.05)$ adsorbsiyon gözlenmiştir.

Tablo 6. 10 ng.mL $\mathrm{mL}^{-1}$ OTA ve 5\% zeolit içeren tampon çözeltilerde karıştırma süresine bağlı OTA geri alma düzeyleri (\%)

\begin{tabular}{ccccc}
\hline & \multicolumn{5}{c}{ Adsorban Tipi } \\
\hline Karıștırma Süresi (dk) & $\mathbf{C N}$ & $\mathbf{C M}$ & $\mathbf{N T}$ & $\mathbf{M T}$ \\
\hline $\mathbf{3 0}$ & $21.04^{\mathrm{aA}} \pm 1.47$ & $34.91^{\mathrm{aB}} \pm 3.64$ & $39.10^{\mathrm{aB}} \pm 0.33$ & $45.7^{\mathrm{a}} \pm 4.55$ \\
$\mathbf{6 0}$ & $23.09^{\mathrm{aA}} \pm 1.88$ & $51.25^{\mathrm{bB}} \pm 2.34$ & $60.52^{\mathrm{bB}} \pm 2.45$ & $65.77^{\mathrm{bC}} \pm 3.64$ \\
$\mathbf{9 0}$ & $52.84^{\mathrm{bA}^{\mathrm{B}}} \pm 2.26$ & $50.88^{\mathrm{bA}} \pm 1.81$ & $65.61^{\mathrm{bB}^{\mathrm{B}}} \pm 2.42$ & $73.17^{\mathrm{cC}} \pm 0.43$ \\
$\mathbf{1 2 0}$ & $53.82^{\mathrm{bA}} \pm 1.28$ & $60.62^{\mathrm{cA}} \pm 3.63$ & $83.76^{\mathrm{B}^{\mathrm{B}}} \pm 5.14$ & $91.10^{\mathrm{dB}} \pm 4.15$ \\
\hline
\end{tabular}

*: Sonuçlar 3 tekerrür ortalaması \pm Standart Sapma şeklinde verilmiştir.

aA:Küçük harfler sütunlar arası farklılıkları, büyük harfler satırlar arası farklılıkları ifade etmektedir. 

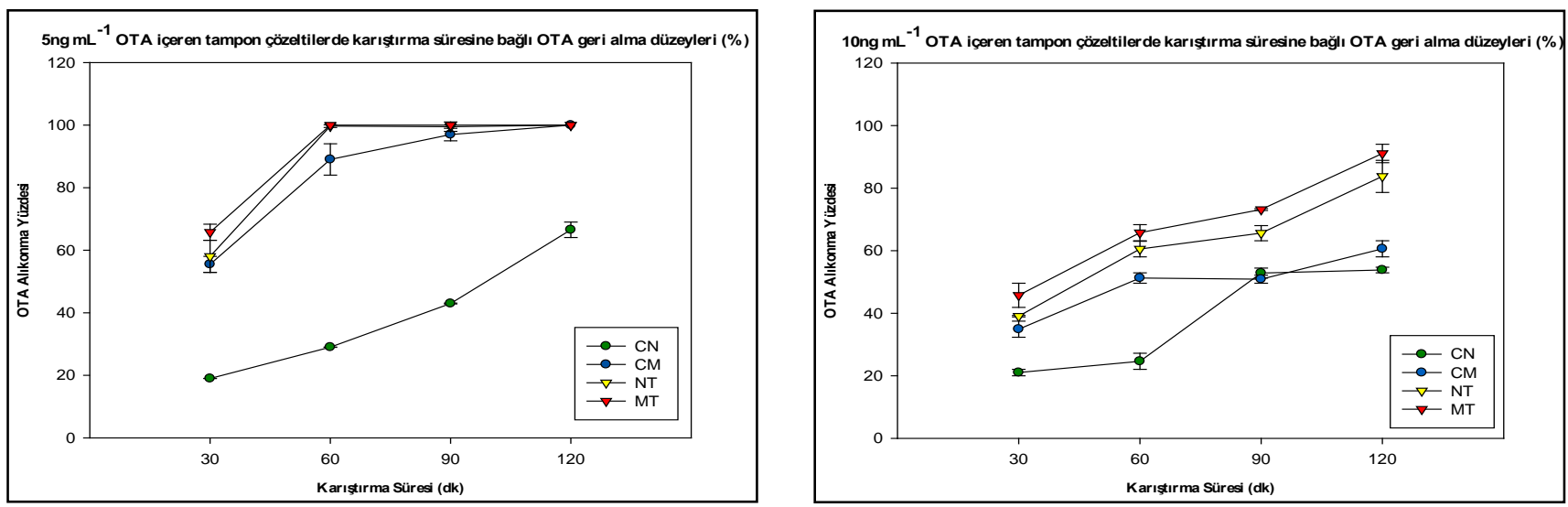

Şekil 5.5 ve 10 ng.mL ${ }^{-1}$ OTA içeren tampon çözeltilerde karıştırma süresine bağlı OTA geri alma düzeyi (\%)

Doğal ve modifiye zeolitlerin OTA alıkoyma düzeylerine tampon çözeltiye ilave edilen OTA miktarının ve karıştırma süresinin ortak etkisi Şekil 6. da gösterilmiştir. Tampon çözeltiye ilave edilen
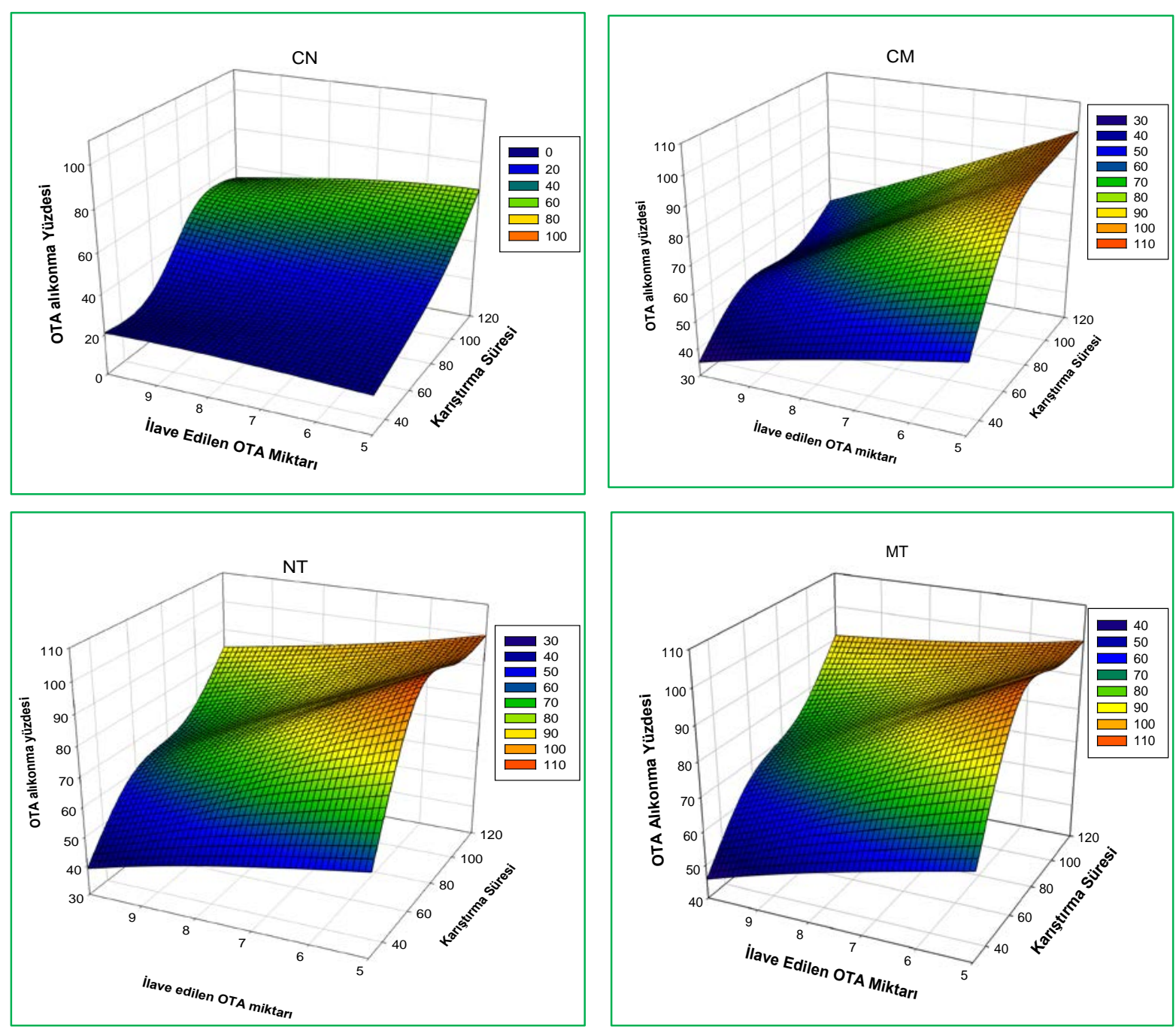

Şekil 6. Doğal ve modifiye zeolitlerin OTA alıkoyma düzeylerine tampon çözeltiye ilave edilen OTA miktarının ve karıştırma süresinin ortak etkisi. CN: 1-3 mm boyutlu doğal zeolit (Normal form); CM: 1-3 mm boyutlu modifiye zeolit (Modifiye form); NT: $100 \mu \mathrm{m}$ boyutlu doğal zeolit (Normal toz form); MT: $100 \mu \mathrm{m}$ boyutlu modifiye zeolit (Modifiye toz form) 
OTA miktarı arttıkça, tüm zeolit tiplerinde OTA adsorbsiyon kapasitesinin azaldığı, ancak karıştırma süresinin arttırılmasının adsorbsiyon kapasitesini olumlu yönde etkilediği görülmektedir. Yüzey modifikasyonu uygulanmamış ve 1-3 mm boyutundaki CN örneklerinin OTA adsorbsiyon kapasitesinin hem 5 hem de 10 ng. $\mathrm{mL}^{-1}$ OTA içeren tampon çözeltiler için diğer zeolit tiplerine kıyasla oldukça düşük düzeyde olduğu belirlenmiştir. ODTMA ile DZ’lerde gerçekleştirilen modifikasyon işlemi sonucunda OTA adsorbsiyonu hem 5 hem de 10 ng.mL $\mathrm{mL}^{-1}$ OTA içeren tampon çözeltilerde daha kısa sürede ve daha yüksek miktarlarda gerçekleşmiştir.

\section{4. Üzüm Suyu Numune Denemeleri}

Üzüm suyu denemelerinde, çalışmanın ilk üç bölümünde, adsorbanların OTA adsorbsiyonu için optimum tutuklama süre ve sıcaklıklarından yola çıkılarak, analizler gerçekleştirilmiştir. Buna göre, tüm zeolit tipleri için maksimum adsorbsiyonun belirlendiği miktar, karıştırma sıcaklığı ve sürenin sırasıyla $5 \%, 45{ }^{\circ} \mathrm{C}$ ve $120 \mathrm{dk}$ olduğu görülmüştür. Ancak adsorbsiyon ortamı artık tampon değil de gerçek gıda ortamı olduğundan 10 ng.mL $\mathrm{mL}^{-1}$ OTA içeren üzüm suyuna 5\% oranında zeolit ilave edilmiş, 30 dakika sürenin yetersiz olabileceği düşünülerek, 60, 90 ve $120 \mathrm{dk}$ süresince $45^{\circ} \mathrm{C}$ 'de karıştırma işlemi gerçekleştirilmiştir. Bu proses sonunda elde edilen veriler Tablo 7 ve Şekil 5'te ifade edilmiştir.

Tablo 7. 10ng.mL $\mathrm{mL}^{-1}$ OTA ve 5\% zeolit içeren üzüm suyu örneklerinde OTA geri alma düzeyleri (\%)

\begin{tabular}{ccccc}
\hline & \multicolumn{4}{c}{ Adsorban Tipi } \\
\hline Karıştırma Süresi & $\mathbf{C N}$ & $\mathbf{C M}$ & $\mathbf{N T}$ & $\mathbf{M T}$ \\
\hline $\mathbf{6 0}$ & $7.43^{\mathrm{aA}} \pm 0.37$ & $14.12^{\mathrm{aA}} \pm 0.36$ & $34.17^{\mathrm{aB}} \pm 7.26$ & $44.45^{\mathrm{aC}} \pm 3,63$ \\
$\mathbf{9 0}$ & $10.78^{\mathrm{bA}} \pm 2,90$ & $13.86^{\mathrm{aA}} \pm 1.45$ & $40.60^{\mathrm{aB}} \pm 1.81$ & $58.60^{\mathrm{bC}} \pm 1,82$ \\
$\mathbf{1 2 0}$ & $13.99^{\mathrm{cA}} \pm 1.63$ & $26.07^{\mathrm{bB}} \pm 0.55$ & $75.30^{\mathrm{bC}} \pm 3.63$ & $89.68^{\mathrm{cD}} \pm 1.48$ \\
\hline
\end{tabular}

*: Sonuçlar 3 tekerrür ortalaması \pm Standart Sapma şeklinde verilmiştir.

aA:Küçük harfler sütunlar arası farklılıkları, büyük harfler satırlar arası farklılıkları ifade etmektedir.

Araştırma sonuçlarına göre, $100 \mu \mathrm{m}$ boyutunda olan gerek normal gerekse de yüzey modifikasyonu uygulanmış toz formdaki zeolitler, 120 dakika karıştırma süresi sonunda en yüksek adsorbsiyon oranını gerçekleştirmiştir. Karıştırma işlem süresi arttıkça adsorbsiyon oranı önemli düzeyde $(\mathrm{p}<0.05)$ artmıştır. Zeolit boyutunun arması, OTA ile etkileşime giren yüzey alanının daralmasına, dolayısıyla da materyallerin adsorbsiyon kapasitenin önemli ölçüde azalmasına $(p<0.05)$ neden olmuştur. Karıştırma işlem süresi arttıkça tüm örnekler için adsorbsiyon oranı önemli düzeyde artmıştır. En yüksek adsorbsiyon oranı 89.68\% ${ }^{ \pm 1.48}$ ile MT örneğinde gerçekleşmiştir. 
Üzüm suyu numunelerinin regresyon analiz sonuçları incelendiğinde, karıştırma süresi ile örneklere ilave edilen zeolitlerin OTA adsorbsiyon düzeyleri arasında oldukça iyi bir korelasyon olduğu görülmektedir. Karıştırma süresinin artması ile yüzey alanı modifikasyon işleminin etkinliğinin fark edilir bir şekilde arttı̆̆ı, modifikasyon uygulanmamış örneklere kıyasla modifikasyon uygulanmış örneklerin adsorbsiyon düzeylerinin önemli düzeyde $(p<0.05)$ daha iyi olduğu belirlenmiştir. En yüksek determinasyon katsayısı $\left(\mathrm{R}^{2}\right)$ en yüksek adsorbsiyon düzeyinin belirlendiği MT örnekleri için elde edilmiştir.

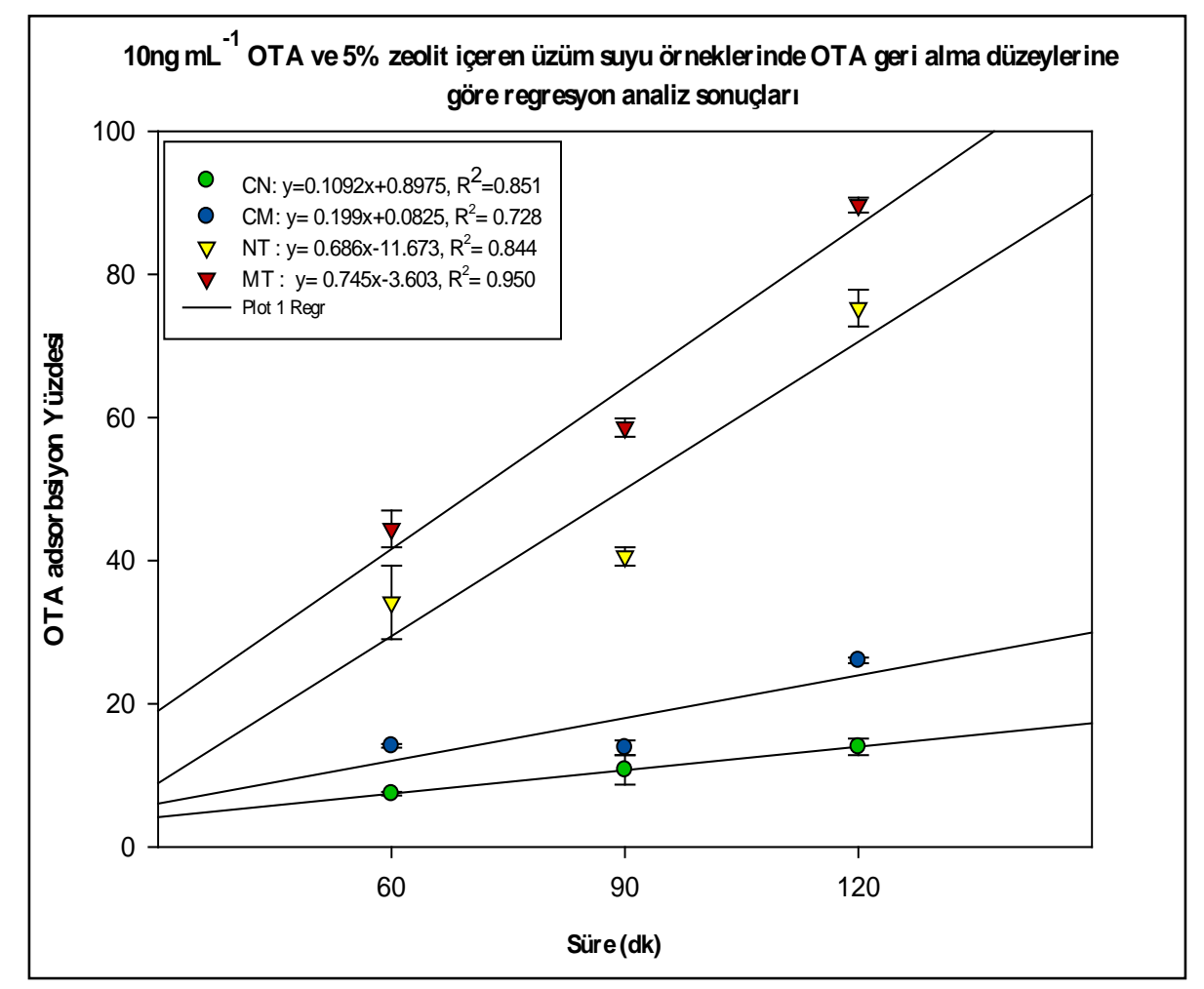

Şekil 5. 10ng.mL $\mathrm{mL}^{-1}$ OTA ve 5\% zeolit içeren üzüm suyu örneklerinde OTA geri alma düzeylerine göre regresyon analiz sonuçları

Üzüm suları için Türk gıda kodeksi ve Avrupa komisyonu tarafından OTA için belirlenen 2 ng.mL ${ }^{-1}$ yasal limit değeri düşünüldüğünde, 10 ng.mL ${ }^{-1}$ OTA içeren üzüm suyunun OTA içeriği 45 ${ }^{\circ} \mathrm{C}^{\prime}$ de $120 \mathrm{dk}$ karıştırma süresi sonunda limit değerin altına düşerek yaklaşık 1.03 ng.mL ${ }^{-1}$ düzeyine indirilebileceği belirlenmiştir. $\mathrm{Bu}$ sonuç, hâlihazırda meyve suyu sektöründe adsorban olarak kullanılan aktif kömüre alternatif olarak zeolitlerin de kullanılabileceğini ortaya koymaktadır.

\section{Sonuçlar ve Öneriler}

Araştırma sonuçlarına göre, tampon çözelti OTA miktarı arttıkça hem toz form hem de doğal zeolitin adsorbsiyon kapasitelerinde azalma eğilimi gözlenmiştir. 1-3 mm’lik ve toz zeolit 
örneklerindeki çalışmalara göre; yüzey alanı arttıkça adsorbsiyon kapasitelerinin arttı̆̆ belirlenmiştir. Kullanılan zeolit miktarı arttıkça adsorbsiyon kapasitesi artmıştır. Tampon denemelerinde $5 \%$ oranında ilave edilen zeolit miktarlarında maksimum adsorbsiyon elde edildiğinden, süre ve sıcaklık çalışmalarında bu oran kullanılmıştır. Yüzey modifikasyonu adsorbsiyon süresini kısaltmıştır. Yüzey modifikasyonu yapılan zeolitin normal zeolite göre adsorbsiyon kapasitesinin daha fazla olduğu belirlenmiştir. İşlem sıcaklığının artması adsorbsiyon kapasitesini iyileştirmiştir. 5\% zeolit ilave edilmiş $10 \mathrm{ng} \cdot \mathrm{mL}^{-1}\left(10 \mu \mathrm{g} / \mathrm{L}^{-1}\right)$ OTA içeren üzüm suyu örneklerinde 120 dakika sonunda, gerek normal gerekse de modifiye zeolit $83-85 \%$ oranında ortamdaki OTA’yı adsorbe etmiştir. Yapılan çalışmalar sonucunda yüzey modifikasyonu yapılmış olan zeolitin sıcaklık artışı, süre artışı, miktar artışı gibi durumlarda normal zeolite oranla adsorpsiyon kapasitesinin daha yüksek olduğu görülmüştür.

Bununla birlikte, gerek doğal zeolit gerekse de modifiye zeolit uygulamaları sonucu üzüm suyunun kimyasal bileşiminde, özellikle zeolitlerin yüksek iyon değişim kapasitesi ve insan sağlığ açısından oldukça önemli olan fenolik bileşiklerin tutulumu gibi konular düşünüldüğünde, örneklerin mineral madde kompozisyonu ve fenolik bileşik kompozisyonunda meydana gelen değişimler bu çalışmada ortaya konulamamıştır. Bu çalışmanın ışığında, zeolitlerin kullanımı sonrası üzüm suyunda meydana gelebilecek mineral madde ve fenolik bileşik değişikliklerini ortaya koyacak yeni çalışmalara ihtiyaç duyulmaktadır. Üzüm sularında, Türk gıda kodeksi ve Avrupa komisyonu tarafından OTA için belirlenen 2 ng.mL ${ }^{-1}$ yasal limit değeri düşünüldüğünde, doğal ve modifiye zeolitin, doğru miktar, işlem süresi ve sıcaklığı kullanıldığında, aktif karbona alternatif olarak doğal adsorban olarak kullanılabileceği sonucuna varılmıştır.

\section{Teşekkür}

$\mathrm{Bu}$ çalışma, Giresun Üniversitesi Bilimsel Araştırma Projeleri Koordinasyon Birimi (BAP, Proje No: FEN-BAP-A-140316-35) tarafından desteklenmiştir.

\section{Kaynaklar}

Akova, Y., (2009). Kuru Üzüm, T. C. Başbakanlık Dış Ticaret Müsteşarlığı İhracatı Geliştirme Etüd Merkezi Sektör Raporu, 2009.

Battilani, P., Giorni, P., Pietri, A. (2003). Epidemiology of Toxin- Producing Fungi and Ochratoxin A Occurrence in Grape. European Journal of Plant Pathology, 109, 715-722.

Battilani, P., Magan, N., Logrieco, A. (2006). European research on ochratoxin A in grapes and wine. Int $J$ Food Microbiol. 111:2-4.

Bilgin, Ö., Koç. B. (2013). Doğal zeolitlerin çevre kirliliği kontrolünde kullanımı. Turkish Journal of Scientific Reviews, 6(1), 169-174.

Breyden, W. L. (2007). Mycotoxins in The Food Chain: Human Health Implications, Asia Pac. J. Clin. Nutr. (16), 95- 101. 
Cabaroğlu, T., Yılmaztekin, M. (2006, Kasım). Üzümün bileşimi ve insan sağlığı üzerine etkileri. Buldan Sempozyumu (s. 999-1004). Denizli. Pamukkale Üniversitesi.

Daković, A., Tomašević-Čanović, M., Rottinghaus, G., Dondur, V., Mašić, Z. (2003). Adsorption of ochratoxin A on octadecyldimethyl benzyl ammonium exchanged-clinoptilolite-heulandite tuff. Colloids and Surfaces B: Biointerfaces, 30(1-2), 157-165.

European Comission. (2006). Setting maximum levels for certain contaminants in foodstuffs (Text with EEA relevance). Official Journal of the European Union, No 1881.

Jackson, L. S., Al-Taher, F. (2008). Factors Affecting Mycotoxin Productions in Fruits, Mycotoxins in Fruits and Vegetables ( Barkai- Golan, R., Paster, N. Eds.), Academic Pres, UK, pp75- 105.

Jha, B., Singh, D. N. (2016). Fly ash zeolites, Advanced Structured Materials, Chaper 2, Basics of zeolites.

Kabak, B., Var, I. (2014). Mikotoksinlerin Detoksifikasyonunda Adsorban Maddelerin Kullanımı. Gıda ve Yem Bilimi Teknolojisi Dergisi, 8,49-56.

Lamprecht, M., Bogner, S., Steinbauer, K., Schuetz, B., Greilberger, J. F., Leber, B., Oberwinkler, T. (2015). Effects of zeolite supplementation on parameters of intestinal barrier integrity, inflammation, redoxbiology and performance in aerobically trained subjects. Journal of the International Society of Sports Nutrition, 12(1), 40.

Malir, F., Ostry, V., Pfohl-Leszkowicz, A., Malir, J., \& Toman, J. (2016). Ochratoxin A: 50 years of research. Toxins, 8(7), 191.

Margeta, K., Logar, N. Z., Šiljeg, M., Farkaš, A. (2013). Natural zeolites in water treatment-how effective is their use. Water treatment, 5, 81-112.

Mercurio, M., Mercurio, V., de'Gennaro, B., de'Gennaro, M., Grifa, C., Langella, A.,Morra, V. (2010). Natural zeolites and white wines from Campania region (Southern Italy): a new contribution for solving some oenological problems. Periodico di Mineralogia, 79(1), 95-112.

Narayanasamy, P. (2006). Postharvest Pathogens and Disease Management, John Wiley \& Sons, Inc., Hoboken, New Jersey, USA, 582p, 2006.

Pasinli T., Henden E. (2013). Solid Phase Extraction of Zearalenone (ZEN) from Beer Samples Using Natural Zeolite Clinoptilolite and Organo-Zeolites Prior to HPLC Determination. Ekoloji 22(89): 57-66.

RASSF, 2020: https://webgate.ec.europa.eu/rasff-window/portal/?event=searchResultList (Erişim Tarihi, Ekim 2020)

Seo, J. A., Yu, J. H. (2005). Toxigenic Fungi and Mycotoxins. In Handbook of Industrial Mycology, Edited by Z. An., Marcell Dekker Inc, 270 Madison Avenue, New York, NY 10016, 749p.

Sherif, S. O., Salama, E.E., \& Abdel-Wahhab, M. A. (2009). Mycotoxins and child health: The need for health risk assessment. International journal of hygiene and environmental health, 212(4), 347-368.

Tomašević-Čanović, M., Daković, A., Rottinghaus, G., Matijašević, S., \& Đuričić, M. (2003). Surfactant modified zeolites-new efficient adsorbents for mycotoxins. Microporous and mesoporous materials, 61(1), 173-180.

Top, A., Ülkü, S. (2004). Silver, zinc, and copper exchange in a Na-clinoptilolite and resulting effect on antibacterial activity. Applied Clay Science, 27, 13-19.

Var, I., Kabak, B., Erginkaya, Z. (2008). Reduction in ochratoxin A levels in white wine, following treatment with activated carbon and sodium bentonite. Food Control, 19(6), 592-598.

Varga, J., Kocsubé, S., Péteri, Z., Vágvölgyi, C., Tóth, B. (2010). Chemical, physical and biological approaches to prevent ochratoxin induced toxicoses in humans and animals. Toxins, 2(7), 1718-1750.

Wasielewski, S., Rott, E., Minke, R., Steinmetz, H. (2018). Evaluation of different clinoptilolite zeolites as adsorbent for ammonium removal from highly concentrated synthetic wastewater. Water, 10(5), 584.

Zimmerli, B., Dick, R. (1996). Ochratoxin A in table wine and grape-juice: occurrence and risk assessment. Food Addit. Contam. 13:655-668. 